\title{
General aspects of COVID-19 and its handling by anesthesiologists
}

\author{
Clara de Oliveira e Souza ${ }^{1}$ \\ Juliana Schvartz ${ }^{1}$ \\ Kylza Azevedo ${ }^{1}$ \\ Marco Túlio Vilarinho' \\ Matheus Deco' ${ }^{1}$ \\ Noeli Mofati Lima ${ }^{1}$ \\ Bruno Vítor Martins Santiago ${ }^{2}$
}

\section{ABSTRACT}

Anesthesiologists play a crucial role in the management of critically ill patients, both in the leadership of rapid response teams for orotracheal intubation, and in the operating room. Therefore, they become extremely exposed. Discussing preventive strategies and conducting team training, with emphasis on paramentation of personal protective equipment and airway algorithms, are fundamental to improve outcomes. This study addresses the main characteristics of the COVID-19 with focus on the handling of the disease by anesthesiologists, bringing epidemiologic data from Brazil and the world, as well as the impact this new virus might have on the health system.

KEY WORDS: COVID-19; Anesthesiology; Breathing Problems; Prevent

\section{INTRODUCTION}

At the end of 2019, a new coronavirus was identified as the cause for several pneumonia cases in Wuhan, a city in the province of Hubei, China [1]. The acute respiratory disease, caused by a new coronavirus (SARS-CoV-2, previously known as 2019-nCoV) and now called coronavirus disease - 19 (COVID-19), has spread throughout China and received worldwide attention. In January 30 of 2020, the World Health Organization (WHO) officially declared the COVID-19 epidemic as a public health emergency of international interest [2]. The previous coronavirus outbreaks (CoVs) include the severe acute respiratory syndrome (SARS)-CoV and the Middle East respiratory syndrome (MERS) -CoV, previously characterized as agents that represent a huge threat to public health [3].

It is understood that in order to diminish the damages associated to COVID-19, urgent infection and public health measures are needed to limit the global spread of the virus [4]. The immediate implementation of appropriate prevention and infection control measures is a critical and integral part of the clinical handling of patients and must be initiated at the patient's entry point at the hospital. The standard precautions include hand hygiene; use of personal protective equipment (PPEs) to prevent the direct contact with blood, bodily fluids, secretions (including respiratory secretions) and non-intact skin [5]. Another important factor is the attention and special efforts to protect or reduce the transmission to susceptible

\footnotetext{
${ }^{1}$ Medical Student, Estácio de Sá University, Rio de Janeiro, Brazil.

Correspondence author: Clara de Oliveira e Souza

Email: clara.souzaoliveiraa@gmail.com

Address: Rua do Bispo,83, Rio de Janeiro, Brazil

Postcode: 20261-063

Contact: +55 61999615454

${ }^{2}$ Anesthesiology Clinic, Marcilio Dias Naval Hospital, Brazilian Navy, Rio de Janeiro, Brazil. Graduate Program in Medical Sciences - PGCM, Faculty of Medical

Sciences, Rio de Janeiro State University - Maracanã, Brazil.
} 
populations, including children, health professionals and elders [3]. It is valid to point out that the most severe disease afflicts the eldest, thus a bigger worry is needed with this age range [6].

In regards to anesthesiology, the biggest challenge is in the assistance to the patient with suspected or confirmed COVID-19, as all the services must have welldefined flows and processes for the treatment of those patients and the protection of the involved professionals [7]. Although, in pandemic times, all the patients might present the risk of carrying the virus, it is recommended that a surgical room is designated to the treatment of the critical patients [8-9]

As recommended by the Brazilian Anesthesiology Society (SBA), the use of PPEs, which are in agreement with the international suggestions, are essential to the adequate handling of the patient [10]. Specific recommendations with airway manipulation, team organization, preparation of the surgical room and materials must be taken in order to prevent the contamination of the involved profe contamination of the involved professionals and the spread of the virus [9-11]. Furthermore, mechanical ventilation specificities must be taken with COVID-19 patients [12].

The COVID-19 outbreak has become a clinical threat to the general population and health professionals around the world. In this review, we seek to synthetize the most recent research progress about the new COVID-19, how (S) should affect the brazillian Unified Health System (SUS). In addition, we will discuss the current treatment and the scientific advances in the context of anesthesiology in the combat against the pandemic. This is because the anesthesiologists are specialists that have access to the airways constantly and will be in the frontlines of the treatment of several COVID-19 patients; therefore, they must be ready for this treatment [11]. Furthermore the surgery room is a complex environment with many interested parties, thus challenging the alignment of interests and worries of every party.

\section{METHODS}

A bibliographic search was performed through the search sources constituted by electronic resources in the following databases: Latin American and Caribbean Literature in Health Sciences (LILACS), Health Information from the National Library of Medicine (Medline), Webo Science, Scopus and the electronic library Scientific
Eletronic Library On-line (SciELO), published from 2015 to 2020 .

The descriptors used were: Coronavirus infection:Anesthesiology, Intubation; Protective Devices, in English, Spanish and Portuguese.

It should be noted that the aforementioned descriptors are found in the Health Sciences Descriptors (DeCS).

Data collection took place during March 2020. Duplicate articles and those that were not in the researched language were excluded. After the exploratory analysis of the articles, 35 articles were selected, which addressed the topic of interest.

\section{DISCUSSION}

1. Context of the virus in Brazil and the world

In October of 2019, began the now known COVID-19 pandemic. The coronavirus causes flu-like symptoms, which may be light or severe depending on the affected population. In the risk population, like elders or immunosuppressed, the virus may lead to a severe acute respiratory syndrome, with high mortality rates, reaching up to $17 \%$ of elders over 80 years old in China, compared to $5 \%$ to the general population [13]. The high transmissibility of the virus is the cause of the alarming situation the world is in today, and due to the approximation the contemporaneous times brought, the virus can reach regions far away from where its transmission began [14].

Italy has a private and a public health service, as well as a majorly elderly population. In the last few months, we have seen its society collapsing over the amount of infected and dead people, reaching 213000 and 29315, respectively, data presented by the Italian government in May 05th of 2020. The ruin of the health system ere up to 21 days and, also, due to the amount of beds, considerably inferior to the amount needed to face the crisis [14].

Brazil began its transmissibility containment measures in March 13th of 2020, warning its population about the importance of quarantine and the looming danger. Currently, the country follows the pattern seen in Italy, with a vertiginous rise in the number of cases, lack of testing vaterial and protection equipment for the lack of westing a vertiginous iise in the number of cases, hearth professionals, as well as 7921 deaths and 114715 confirmed cases in the country [15]. It is important to highlight that the Brazilian territory is in the 71th day since

2. COVID-19 implications on the health system

COVID-19 had its start in Wuhan (China) and quickly spread to other Chinese territories and to beyond its borders [16]. Studies point out that the disseminationoccurs mainly through saliva droplets or through the nasal region, much like the way the flu is transmitted [17].

The pathogen liberated by the respiratory secretions of an infected individual may contaminate someone by the cough, the sneeze, or even by the speech. Besides, the contamination may also happen when touching an infected surface and later touching eyes, mouth and nose [17]. Thus, the exponential increase in the number of cases may be explained by the high virus transmissibility, happening both in symptomatic and asymptomatic individuals [18].

Due to the lack of a specific vaccine as a

prophylactic strategy for the containment of this new infirmity, the so-called "non-pharmacological and, thus, avoid a demand higher than what the health system can take. The idea is that the general population follows a set of terminations to avoid the spread of the virus [19].

A research conducted in Great Britain showed that the epidemiologic containment plan can be based on five pillars, with them being: isolation within the homes of confirmed or suspected cases, the voluntary house quarantine of the population, the distancing to people over 70 years old, social distancing and interruption of activities in schools and universities. With those actions in mind, the demand for health services might lessen, allowing a less chaotic scenario within the health units before this pandemic. The adapted graph below (figure 1), taken from an Imperial College study, shows the importance of those five pillars in this global health

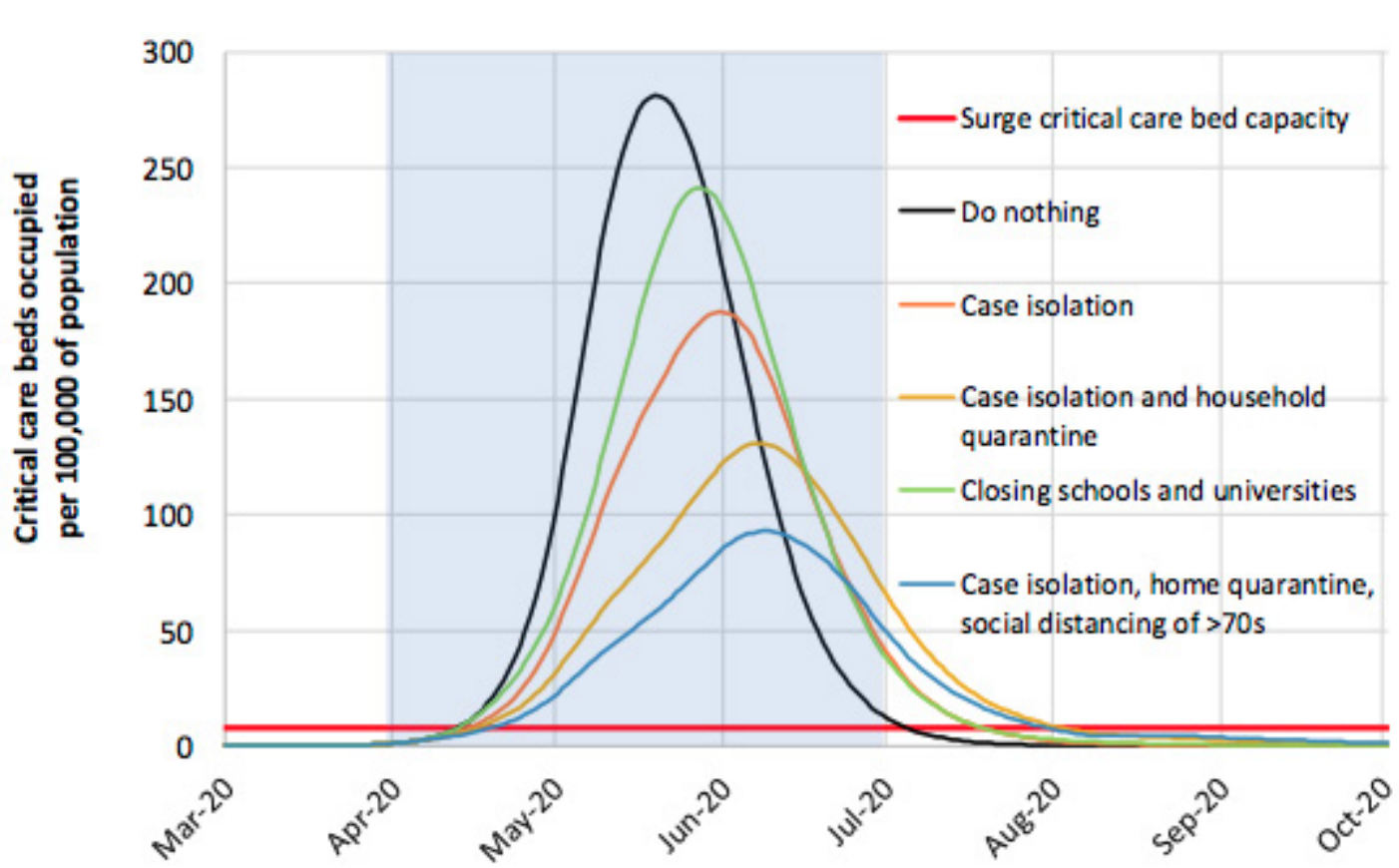

Figure 1. Imperial College COVID-19 Response Team: Mitigation strategy scenarios for Great Britain showing requisites for intensive care beds [19].

Subtitle: The green line shows a mitigation strategy incorporating the closing of schools and universities. the orange line shows the isolation of cases; the yellow line shows distancing and home quarantine; and the blue line shows the case isolation, home quarantine and the distancing of people over 70 years old. The blue shade shows the period of three months those interventions shall remain in the place [19] 
This way, despite the higher mortality risks of that there is an already preexisting frailty in the system the disease being related to advanced age and other from resource rationalization, including intensive care bed. When the demand might lead to a saturation of the health system [20- access becomes limited, the patient treatment is delayed, 21]. This fact can be exemplified by the collapse of the and long waiting lines are formed. Considering that the Italian health system, which was not able to contain the ICU has a decisive role in the patients' survival, the delay increase of cases. Thus, it had lethal consequences, as in the access to the beds leads to a negative impact in the it became impossible to treat so many critical patients clinical results and in the mortality [23]. simultaneously [22].

In face of this situation, the arrival of the new virus in Brazil puts to test the vigilance system of the vius in Brazl puts to test the vigilance system of the countion ta ingestment of the SUS [21]. The worry stemming from the stemming from the COVID-19 takes place due to the fact

The handling of COVID-19 patients needs access to intensive therapy with the use of resources from this hospital unit [24]. Therefore, the decrease in the number of hospital establishments and hospital beds seen in the last years (figure 2), corroborates with the alert to the impacts of this disease in the health system [25].

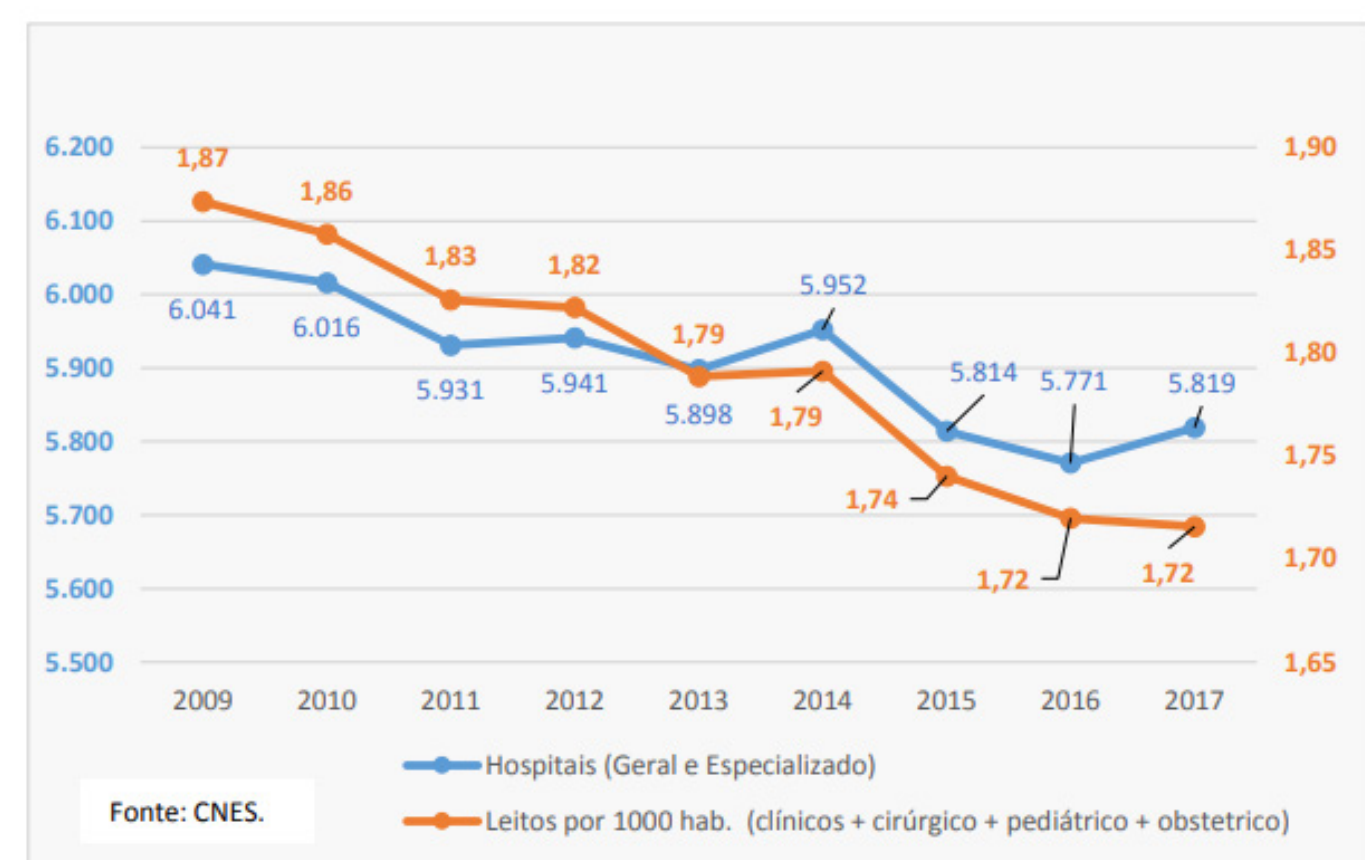

Figure 2. Adapted from the PROADESS Informative Bulletin, no 4, Feb./2019: Evolution of the hospital network - Brazil, 2009 - 2017 [25].

This way, with the ever-growing case increase and maybe due to the saturation of intensive care beds, it will not be uncommon to have the necessity to treat patients afflicted by COVID-1 9 in surgical centers [25]. Therefore, it is fundamental that the anesthesiologist doctor is ready to deal with those patients within the surgical environment.

1. Covid-19: The role of the anesthesiologist

In the anesthesiologist's case, there is a special care about the patients that need manipulation of the airways and mechanical ventilation during surgical. procedures, in intensive care or in the emergency service [24]. Thus, it is imperative the implementation of measures to mitigate the perioperative transmission.

As we have learned with the 2002 SARS-CoV outbreak in Toronto, the hospital transmission represents a severe threat to health systems and represents a significant load for the hospital systems and communities [26]. To the anesthesiologist and other health professionals, for their individual protection, in routine procedures and treatments, some standard precaution measures are some stand of prect and indirect contact with blood, bodily fluids, secretions, excretions, mucous, non-integral skin and contaminated articles or equipment, in order to reduce the possibility of transmission of the new coronavirus to the health worker, as well as from patient to patient, through the hands of the professional, the daily exposure stemming from the obligations. Besides instigating them to be constantly up to date with the most recent local health authorities and the WHO, as there are new discoveries about the disease daily, and the handling practices lead to a congregation of better approach techniques [10-24].

3.1. Hand hygiene

Cross infections can be avoided with frequent hand washing. It is the most important hygiene measure and must be actively applied [27]. The alcohol-based gels for hand washing must be in every anesthesiologist's working stations [26]. The hand hygiene must be meticulously done according to standard practices, especially after taking off the gloves; after the contact with dirty or infected areas; before touching the anesthesia machine, the anesthesia cart or its contents and after every contact with the patien [27]. Furthermore, it is also made necessary avoid physica contact beyond the strictly necessary for the patient's examination, as well as avoid touching the face, nose and mouth.

3.2. Personal protective equipment (PPE)

As questions were raised about the infection of health professional, it is recommended to the entire institution to develop treatment protocols, provide PPE -

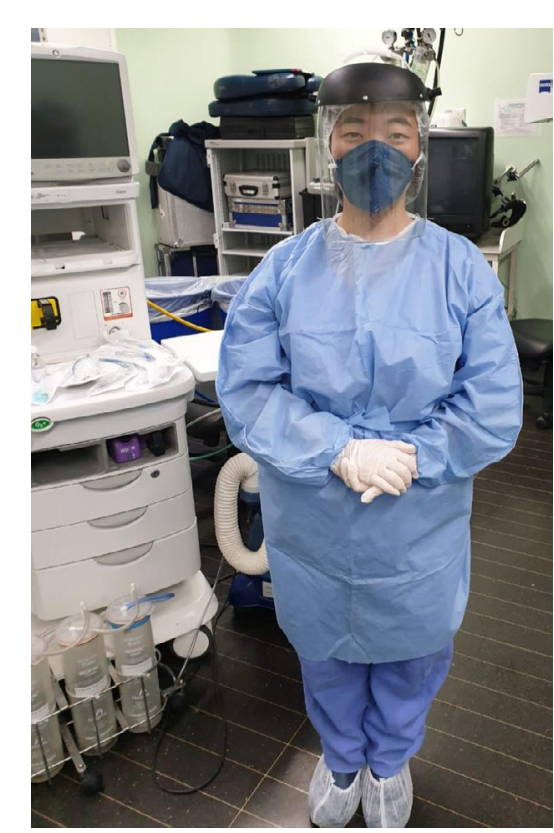

Figure 2. Adequate apparelment for treatment of an infected patient. The use of N95 mask, impermeable gloves, surgical cloak and face protection. surgical mask (N95,PFF2), gloves, non-sterile apron and protective glasses - and undertake adequate training to deal with patients and correct apparelment/ disapparelment. It must be considered doing simulation intubation/extubation exercises using the PPE in a real environment (in situ ) [26-28]. This is an opportunity to promote the correct PPE use among anesthesiologists and identify hurdles regarding the adhesion in order to avoid contamination with the procedure or disapparelment.

When undertaking procedures that generate high risk of respiratory secretion (intubation, aspiration of the airways or sputum induction etc.), it must be used for aerosol precaution, through the use of respiratory protective mask with minimum filtration efficacy of $95 \%$

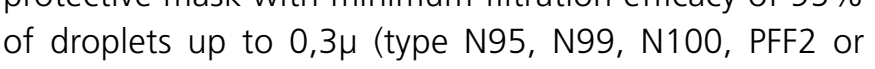
PFF3), as the surgical mask can be used for individual protection, but is protective capacity is reduced, as its seal precarious [24-26]. Disposable and impermeable long sleeved aprons, protective glasses and disposable facemasks are recommended for the medical team on the front lines with risk of exposure [26]. The hand washing is essential before and after putting or removing the PPE.

That said, all the reusable material and equipment used in contaminated or suspected COVID-19 patients must be processed according to the Hospital Infection Control Comittee (HICC) of the institutions, after every se [24]. 
3.3. Manipulation of the airways of a patient with suspected COVID-19 infection (2019-nCoV)

3.3.1. Team preparation

The team's organization is essential when treating confirmed or suspected COVID-19 cases. The team must work with the minimum needed amount and all the professionals must be experienced, especially those who will deal directly with the patient's airways. All the necessary equipment and drugs for the procedure must be prepared before the apparelment in order to avoid the with the external environment. The anesthesiologist that is the most experienced and up to date regarding the COVID-19 specificities must be the team leader, coordinating all the work [7]. Confirmed of suspected 2019 coronavirus cases must be taken to a designated isolated place, and those places must be signalized with slabs fixated in the doors to minimize the team's exposure.

3.3.2. Transfers

Infected cases must be taken to negative pressure rooms. Make sure that a high quality Heat and Moisture Exchange Filter (HMEF), qualified to remove at least $99,97 \%$ of the particles transported by the air with 0,3 microns or more is placed between the endotracheal tube and the reservoir bag during the transfers to avoid the atmosphere contamination [24].

3.3.3. Surgery room

A small surgery room (SR) complex, with anesthesia rooms and anterooms must be prepared only for procedures in patients suspected or confirmed with COVID-19, reducing the contamination risk of other environments. The monitors and equipment used for the anesthesia must be enveloped and disinfected before being used in not infected patients, the anesthesiologist must make a previous preparation of a COVID-19 Kit with all the materials and drugs which will be used in the procedure, minimizing needless exits from the SR [29]. The SR must be a negative pressure environment with a high air exchange frequency (25 per hour), high efficiency air filter, and the doors must remain locked during the surgery to minimize the dissemination of the virus to an external area [7]. In case there is no SR with negative pressre, the posivine pressure system and the a surgical mask when not intubated [29].
3.3.4. Handling of airway and anesthetic technique of choice

The main goal is to reduce the production and movement of aerosols by the patient and do the technique the fastest and most effective way possible. Before the anesthesic induction, an HMEF must be adapted between the respiratory system and the patient, and the other in the experitory branch of the ventilator circuit [7]. The pre-oxygenation with a well-sealed mask is preconized, if possible with a transparent plastic cover over the face mask, limiting the formation of aerosols. Small doses of ketamine $(0.2 \mathrm{mg} / \mathrm{kg})$ intravenously, can be performed to improve patient acceptance (figure 4), avoiding the ventilation with bag valve masks as much . In case it is ineviable, it must be manach 作 with a minimum volume and under low pressure [27-30]. The rapid intubation sequence (RIS) is preconized and must be done by the most experienced professional and with the use of videolaryngoscopes as the first option and other techniques is made difficult due to the PPEs. During laryngoscopy, barrier strategies can be used to reduce the spread of aerosols to the environment (figure 5) [31]. The intubation with an awaken patient must be avoided [7]. The circuit disconnections must be minimized, and if inevitable, the ventilation must be stopped with positive pressure, the pressure limitation valve adjusted to zero and the endotracheal tube must be clamped before doing the disconnection [7].

At the RIS, the neuromuscular blockage with rocuronium $1.2 \mathrm{mg} / \mathrm{kg}$ or succinylcholine must be done with the intent of avoiding cough reflex. For the induction, the ketamine $1,5 \mathrm{mg}-2 \mathrm{mg} / \mathrm{kg}$ must be the drug of choice, save for contraindications, due to its hemodynamic stability and bronchodilator properties. Lidocaine $1.5 \mathrm{mg} /$ $\mathrm{kg}$ may abolish laryngeal reflexes and potentialize anesthetic effects of other substances, being used as a 3 minutes before the induction. Fentanyl and Midazolam are options for sedation and analgesic after orotracheal intubation (OTI), but attention must be paid regarding bradycardia and hypotension. Patients displaying signs of shock must be stabilized before the RIS with the use of norepinephrine in peripheral veins and infusion of $500 \mathrm{~mL}$ of crystalloid, in case of no contraindication. Those same stabilization measures may con necessay after the Ris due to its hypotensive potentio [32].

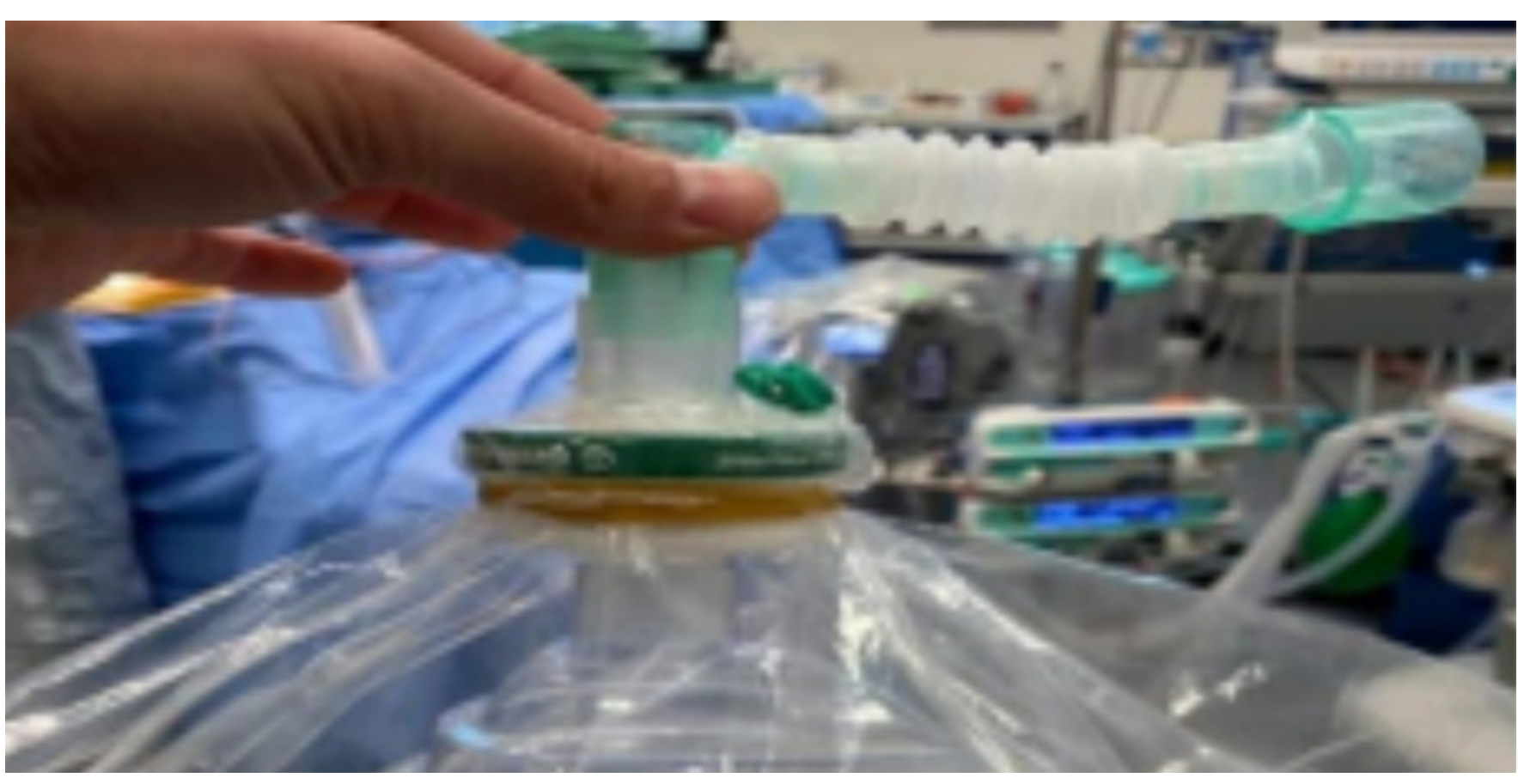

Figure 4 - Pre-oxygenation under facial mask using a plastic tent to minimize the release of aerosols.

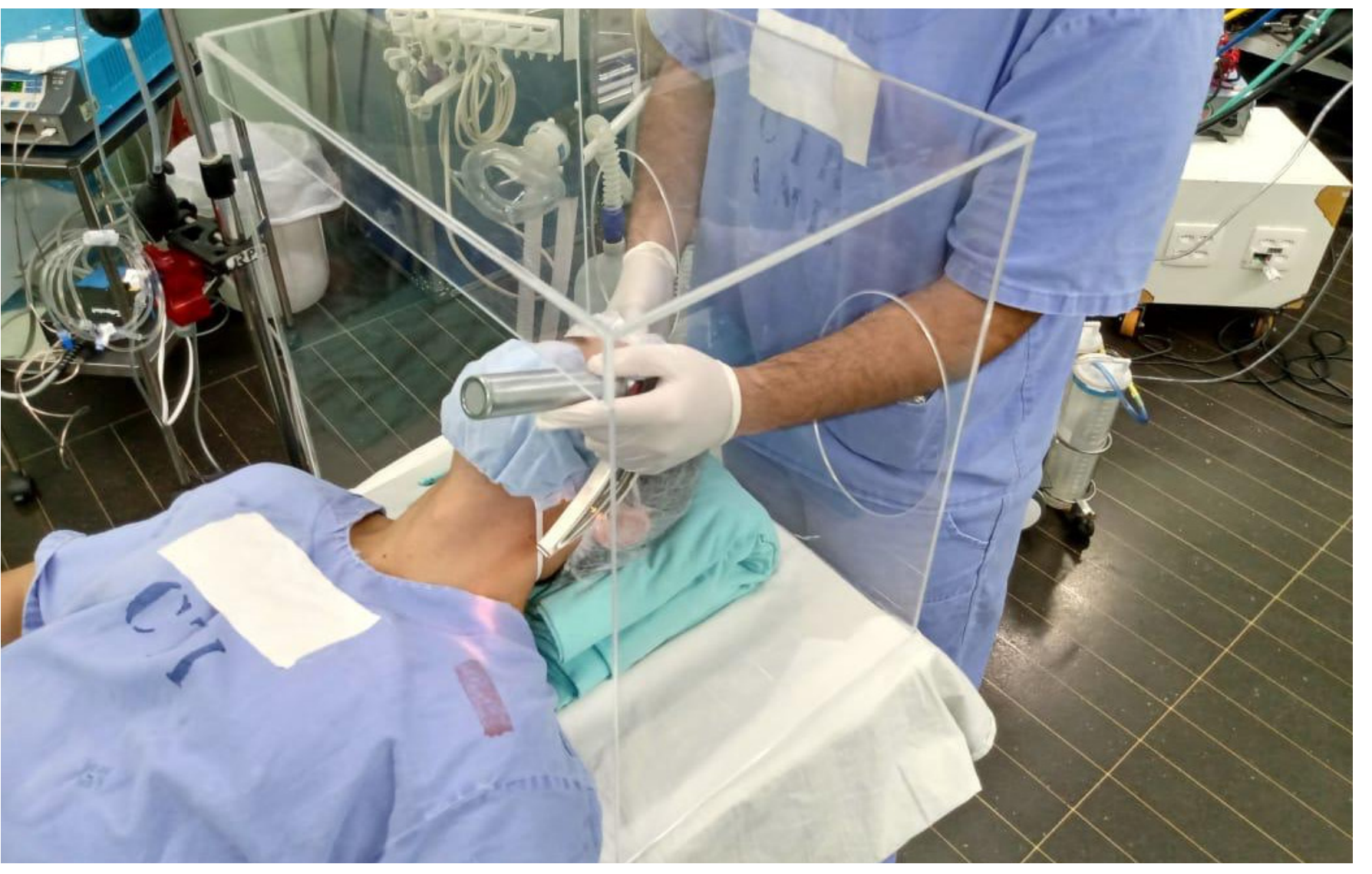

Figure 5 - Barrier Enclosure during Endotracheal Intubation. 
3.3.5. Ventilation strategies

The mechanical ventilation shall use lesser current volumes (4-8 $\mathrm{m} / \mathrm{kg}$ of predicted body weight, PBW) and lower inspiratory pressures (plateau pressure $<30 \mathrm{cmH} 20$ ), which are strongly recommended to patients with acute respiratory distress syndrome (ARDS) [33-35].

The current volume of up to $8 \mathrm{ml} / \mathrm{kg}$ must be reserved if undesired side effects happen, like dyssynchrony and $\mathrm{pH}<7,15$ [32]. Deep sedation must be necessary to control the respiratory unit. Hypercarpnia is allowed as long as it stays in the $\mathrm{pH}$ range of $7.30-7.45$. In patients with moderate or severe ARDS (PaO2/FiO2 < 150), it may with moderate or severe ARDS (PaO2/FiO2 <150), it may be necessary the titrted PEEP elevalon and for those with severe SDRA, it is recommended prone ventilation
$<12$ hours per day), demanding human resources and experience [33-34]

The neuromuscular blockage by continuous infusion should not be used routinely, instead being individualized in patients with moderate-severe ARDS. The disconnection of the patient from the ventilator must be avoided due to PEEP loss and atelectasis. Catheters for the suction of airways and clamping of the endotracheal tube are necessary [34].

\subsubsection{Extubation}

Before extubation, the patient's nose and mouth must be covered with two layers of humidified gauzes to avoid the exposition to secretions during the process, which should take place in the SR, preferably [29]. An endovenous lidocaine dose may be applied to avoid the cough [35]. After being extubated, the patient must use surgical mask during the anesthetic recovery transfer. If there is a need to keep the patient intubated, a mechanical ventilator must be used for ventilation during the transfer [29].

\section{CONCLUSION}

The current outbreak of COVID-19 is expanding rapidly across the world, requiring measures of social isolation, in order to understand the transmission of viruses, activate a spread curve, in order to try to balance the availability of the resources that are ahead, which it is considered a challenge, considering the continental dimensions of the Brazilian territory.

Several health professionals, including anesthesiologists, have managed to adapt to a new reality of care, developing training on how to use required PPE; adapt intubation algorithms and daily based techniques in order to make assistance safer and prevent the dispersion of COVID-19.

As, the anesthesiologist deal directly with airways, they play a key role in the treatment of these patients, whether in the formation of rapid response times for intubation or during procedures performed in the operating room. Discussing infection prevention and control measures, strict adherence to the use and disposal of PPE and preparing for the care of infected patients is essential to improve outcomes and control the spread of COVID-19.

\section{REFERENCES}

1. World Health Organization. (2020). WHO Director-General's remarks at the media briefing on 2019-nCoV on 11 February 2020. Internet] World Health Organization. [acesso em março de 2020]. Disponive em: https//www mo int/dg/speeches/ detail/who-director-general-s-remarks-at-themedia-briefing-on-2019-ncov-on-11-february-2020. 2. Guo, Y. R., Cao, Q. D., Hong, Z. S., Tan, Y. Y., Chen, S. D., Jin, H. J., ... \& Yan, Y. (2020). The origin, transmission and clinical therapies on coronavirus disease 2019 (COVID-19) outbreak-an update on the status. Military Medical Research, 7(1), 1-10. [acessoemmarcode 2020] Disponível 3. Rothan, H. A., \& Byrareddy, S. N. (2020). The epidemiology and pathogenesis of coronavirus disease (COVID-19) outbreak. Journal of autoimmunity, 102433. [acesso em março de 2020]. Disponível em: $\quad$ https://doi:10.1016/j.jaut.2020.102433

4. Song, F, Shi, N., Shan, F, Zhang, Z., Shen, J., Lu, H., .. \& Shi, Y. (2020). Emerging 2019 novel coronavirus (2019-nCoV) pneumonia. Radiology, 295(1), 210-217. [acesso em março de 2020]. Disponível em: https://doi.org/10.1148/radiol.2020200274 5. World Health Organization. (2020). Clinical management of severe acute respiratory infection

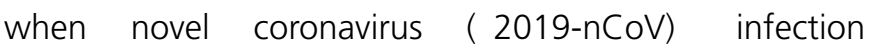
is suspected: interim guidance, 28 January 2020 (No. WHO/nCoV/Clinica/2020.3) World Health Organization. [acessado em março de 2020]. Disponível em: https://apps.who.int/iris/handle/10665/330893
6. Mclntosh, K., Hirsch, M. S., \& Bloom, A. (2020). Coronavirus disease 2019 (COVID-19). 2020]. Disponível em: https://www. uptodate. com/contents/coronavirusdisease-2019-covid-19-epidemiology-virology-clinicalfeatures-diagnosis-and-prevention. Acesso em, 30. features-diagnosis-and-prevention. Acesso em, 30.
[acesso em março de 2020]. Disponível em: https:// [acesso em março de 2020]. Disponível em: https://

7. Wong, J., Goh, Q. Y., Tan, Z., Lie, S. A., Tay, Y. C., Ng, S. Y., \&Soh, C. R. (2020). Preparing for a COVID-19 pandemic: a review of operating room outbreak response measures in a large tertiary hospital in Singapore. Candion Jom canadien d'anesthésie, 1-14. [acesso em março de 2020] Disponível em: https://doi.org/10.1007/s12630-020-01620-9

8. Ti, L. K., Ang, L. S., Foong, T. W., \& Ng, B. S. W. (2020). What we do when a COVID-19 patient needs an operation: operating room preparation and guidance. Canadian Journal of Anesthesia/Journal canadien d'anesthésie, 1-3. Disponivel em: https://doi.org/10.1007/s12630-020-01617-4

9. Chow, N., Fleming-Dutra, K., Gierke, R. \& Roguski, K. Preliminary estimates of the prevalence of selected underlying health conditions among patients with coronavirus disease 2019-United States, February 12-March 28, 2020. Morbidity and Mortality Weekly Report, 69(13), 382. [acesso em 20 de março de 2020]. Disponível em: https://www. cdc gov/coronavirus/2019ncov/casesupdates/summaty. htmI?CDCAA_refVal=htps\%3A\%2F\%2Fww.cdc. gov\%2Fcorona virus\%2F2019-ncov\%2Fsummary.html

10. Ocoronavíruseoanestesiologista. Riode Janeiro: Sociedade Brasileira de Anestesiologia; 2020 [acesso em 20 de março de 2020]. Disponível em: https://www.sbahq.org/ebook

11. Peng, P. W., Wong, D. T., Bevan, D., \& Gardam, M. (2003). Infection control and anesthesia: lessons learned from the Toronto SARS outbreak. Canadian Journal of Anesthesia, 50(10), 989-997. [acesso em março de 2020]. Disponível em: https://doi.org/10.1016/j.bjan.2020.03.002

12. Peng, P. W., Wong, D. T., Bevan, D., \& Gardam, M. (2003). Infectioncontrolandanesthesia:lessonslearnedfrom the Toronto SARS outbreak. Canadian Journal of Anesthesia, 50(10), 989997. [acesso em março de 2020]; 111(4):933-45. Disponível em: $\quad$ http //doiorg/10.1213/ANE.0b013e3181e780f8

13. Guan, W. J., Ni, Z. Y., Hu, Y., Liang, W. H., Ou, C. Q., He, J. X. $\& D u, B$. (2020). Clinical characteristics of coronavirus disease
2019 in China. New England journal of medicine. [acesso em marçode 2020]. Disponívelem:doi:10.1056/NEJMoa2002032

14. Epidemiológica, S., \& de Vigilância, G. Infecção Humana pelo Novo Coronavírus (2019-nCoV). [acesso em março de 2020]. Disponivel em: http://portal.anvisa.gov.br/coronavirus

15. Organização Mundial de Saúde. Folha informativa COVID19 (doença causada pelo novo coronavírus); 2020 [acesso em maio de 2020]; Disponível em: https://www paho org/bra/index php?option=com co

16. Lipsitch, M., Swerdlow, D. L., \& Finelli, L. (2020). Defining the epidemiology of Covid-19-studies needed. New England Journal of Medicine, 382(13), 1194-1196., [acesso em 18 mar 2020]. Disponível em: https://www.nejm.org/doi/full/10.1056/NEJMp2002125

17. Almonacid, L. T., Ortiz, R. G. P., Cabrera-Vargas, L. . María, J. M. O. M. J, Cortés, E. F. S., Vargas, C. M. R., \& Cruz, O. A. G. (2020). Recomendaciones generales para los Servicios de Cirugía en Colombia durante la pandemia COVID-19 (SARS-CoV-2). Revista Colombiana de Cirugía, 35(2), 258-274. ,[acesso em 20 mar 2020]. Disponivel em: https://doi.org/10.1002/bjs.11627

18. Guimarães, H. P., Damasceno, M. C., Braga, M. A., Santana, J. C. B, da Rocha Freitas, A. P, \& da Costa Ribeiro, S. C. Coronavírus e Medicina de Emergência: Recomendaçōes para o atendimento inicial do Médico Emergencista pela Associação Brasileira de Medicina de Emergencia (ABRAMEDE)., [acesso em 19 mar 2020]. Disponível em: http://www.somiti. org.br/arquivos/site/comunicacao/noticias/2020/covid-19/ posicionamento-abramede-coronavirus-020320.pdf

19. CRUZ, A. A. ROSA, A. J. B, ANCHIETA, B. D. O., DANTAS, B., COSTA, C. D. A., BRONZI, E. D. S., ... \& PINTO11 C. E M CONSIDERAC̄ÕES SINTOMÁTICAS E MEDICAMENTOSAS A RESPEITO DO NOVO CORONAVÍRUS: UMA REVISÃO DA LITERATURA SOBRE FARMACOLOGIA, EFEITOS ADVERSOS, FISIOPATOGENIA E FORMAS DE TRATAMENTO DO COVID-19., [acesso em $18 \mathrm{mar}$ 2020]. Disponível em: https://www.imperial.ac.uk/media/ imperial-college/medicine/sph/ide/gida-fellowships/ Imperial-College-COVID19-NPlmodelling-16-03-2020.pdf

20. Dias, V. M. D. C. H., Carneiro, M., de Lacerda Vidal, C. F., Corradi, M. D. F. D. B., Brandão, D., da Cunha, C. A., ... \& 
Waib, L. F. (2020). Orientações sobre Diagnóstico, Tratamento e Isolamento de Pacientes com COVID-19. Journal of Infection Control, 9(2)., [acesso em 18 mar 2020]. Disponível em: $\quad$ https://doi.org/10.1016/50140-6736(20)30211-7

21. Lana, R. M., Coelho, F. C., Gomes, M. F. D. C., Cruz, O. G., Bastos, L. S., Villela, D. A. M., \& Codeço, C. T. (2020). Emergência do novo coronavírus (SARS-CoV-2) e o papel de uma vigilância nacional em saúde oportuna e efetiva. Cadernos de Saúde Pública, 36, e00019620., [acesso em 18 mar 2020]. Disponível em: https://doi.org/10.1590/0102-311X00019620

22. Rosenbaum L. Enfrentando Covid-19 na Itália - Ética, Logística e Terapêutica na linha de frente da epidemia. The New England Journal of Medicine; 18 mar 2020, [acesso em 19 mar 2020]. Disponível em: https://www.nejm.org/ doi/full/10.1056/NEJMp2005492\#article_introduction

23. Goldwasser, R. S., Lobo, M. S. D. C., Arruda, E. F. D., Angelo, S. A., Silva, J. R. L., Salles, A. A. D. \& David, C. M. (2016). Dificuldades de acesso e estimativas de leitos públicos para unidades deterapiaintensivanoestado do Riode Janeiro. Revista de Saúde Pública, 50,19, [acessoem 19 mar 2020]. Disponive em: https://www.redalyc.org/articulo.oa?id=67247719045

24. de Carvalho, A. P. Novo coronavírus (COVID-19). [acesso em 19 mar 2020]. Disponível em: https:// www.sbp.com.br/fileadmin/user_upload/22340dDocCientifico _ Novo coronavirus.pdf

25. Fundação Oswaldo Cruz; Boletim Informativo do PROADESS, número 4; Monitoramento da assistência hospitalar no Brasil (2009-2017); Fev 2019, [acesso em 19 mar 2020]. Disponível em: https://www.proadess.icict. fiocruz.br/Boletim_4_PROADESS_Monitoramento $\% 20$ da\%20assistencia\%20hospitalar_errata_1403.pdf

26. Howell, S. J., Sear, J. W., \& Young, J. D. (2004) Cardiovascular medicine and Moore's Law. [acesso em março de 2020]. Disponivel em: https://doi.org/10.1093/bja/aeh173

27. Kamming, D., Gardam, M., \& Chung, F. (2003). I. Anaesthesia and SARS.; 90(6):715-8.

28. Zucco L, Levy N, Ketchandji D, Aziz M, Ramachandran SK Perioperative considerations for the 2019 novel coronavirus (COVID-19). Anesthesia Patient Safety Foundation; Fev 2020, [acesso em 17 mar 2020]. Disponível em https://www. apsf.org/news-updates/perioperativeconsiderations-for-the-2019-novel-coronavirus-covid-19/

29. Chen, X., Liu, Y., Gong, Y., Guo, X., Zuo, M., Li, J., ... \& Huang, Y. (2020). Perioperative Management of Patients Infected with the Novel CoronavirusRecommendation from the Joint Task Force of the Chinese Society of Anesthesiology and the Chinese Association of Anesthesiologists. Anesthesiology: The Journal of the American Society of Anesthesiologists., [acesso em 17 mar 2020]. Disponivel em: https://doi.org/10.1097/ALN .0000000000003301.

30 - Matava, CT., Yu, J., Denning S. Clear plastic drapes may be effective at limiting aerosolization and droplet spray during extubation: implications for COVID-19. Canadian Journal of Anaesthesia;April2020,[acessoem02mai2020].Disponívelem: https://www.ncbi.nlm.nih.gov/pmc/articles/PMC7124129/

31- Canelli R., Connor CW., Gonzalez M., Nozari A et al. Barrier Enclosure during Endotracheal Intubation New England joum mai 2020 full/10.1056/NEJMc2007589? (2007589?query=featured_coronavirus

32. Associação Brasileira de Medicina de Emergência; Associação de Medicina Intensiva Brasileira; Associação Medica Brasileira. Protocolo de intubação orotraqueal para caso suspeito ou confirmado de COVID-19: 2020. Brasil, 27 mar 2020 [acesso em 30 mar 2020]. Disponivel em: https://wnw.amib.org.br/fileadmin/ user_upload/Protocolo_de_Intubacao_Orotraqueal.pdf 33. Alhazzani, W., Møller, M., Arabi, Y., Loeb, M., Gong, M., Fan, E., ... \& Bin, D. (2020). Surviving Sepsis Campaign., [acesso em 18 mar 2020]. Disponível em: https://www ncbi.nlm. nih gov/pubmed/28101605

34. Fan E, Del Sorbo L, Goligher EC, Hodgson CL, Munshi L, AJ, et al. An Official American Thoracic Society/European Society of Intensive Care Medicine/Society of Critical Care Medicine Clinical Practice Guideline: Mechanical Ventilation in Adult Patients with Acute Respiratory Distress Syndrome. Am J Respir CritCare Med; Maio 2017, [acesso em 18mar 2020]. Disponivel em: $\quad$ https://www.ncbi.nlm.nih.gov/pubmed/28459336

35. Aminnejad, R., Salimi, A., \& Saeidi, M. (2020). Lidocaine during intubation and extubation in patients with coronavirus disease (COVID-19). Canadian Journal of Anesthesia/Journal canadien d'anesthésie, 1-1. [acesso em março de 2020].
Disponível em: https://doi.org/10.1007/s12630-020-01627-2

Funding sources: No funding

Potential conflict of interest: No conflict 